\title{
Electronic Structure of $\left[\mathrm{NiS}_{4}\right]^{-}$Investigated by Single-Crystal EPR and Density Functional Theory
}

\author{
Su-Young Min, ${ }^{1}$ Dong-Youn Noh, ${ }^{2}$ Cheol Ho Choi, ${ }^{1}$ Hong-In Lee ${ }^{1, *}$ \\ ${ }^{1}$ Department of Chemistry, Kyungpook National University, Daegu 702-702, Republic of Korea \\ ${ }^{2}$ Department of Chemistry, Seoul Women's University, Seoul 139-774, Republic of Korea \\ (Received Apr 28, 2012; Revised May 24, 2012; Accepted June 08, 2012)
}

\begin{abstract}
To understand the electronic structure of $\left[\mathrm{NiS}_{4}\right]^{-}$complex ions, two complexes with such $\left[\mathrm{NiS}_{4}\right]^{-}$core, $\mathrm{FcCH}=\mathrm{CHPymCH}_{3}\left[\mathrm{Ni}(\mathrm{dmit})_{2}\right]$ $\left(\mathrm{Pym}=\right.$ pyridinium, $\mathrm{dmit}^{2-}=$ 2-thioxo-1,3-dithiole-4,5-dithiolate $)$ and $\mathrm{FcCH}=\mathrm{CHPymCH}_{3}\left[\mathrm{Ni}(\mathrm{dddt})_{2}\right] \cdot 1 / 2 \mathrm{H}_{2} \mathrm{O} \quad\left(\mathrm{dddt}^{2-}=\right.$ 5,6-dihydro-1,4-dithiin-2,3dithiolato), were synthesized to be characterized by X-ray crystallography, single crystal electron paramagnetic resonance (EPR) and density functional theory (DFT) calculation. Powder EPR spectra show narrow g-anisotropy but the anisotropy is bigger in $\left[\mathrm{Ni}(\mathrm{dmit})_{2}\right]^{-}$than in $\left[\mathrm{Ni}(\mathrm{dddt})_{2}\right]^{-}$, indicating bigger spin density in $\mathrm{Ni}(\mathrm{III}) \mathrm{d}$ orbital of $\left[\mathrm{Ni}(\mathrm{dmit})_{2}\right]^{-}$than in $\left[\mathrm{Ni}(\mathrm{dddt})_{2}\right]^{-}$, which is consistent to DFT results. EPR studies of the crystals of the complexes surprisingly suggest that the $g_{y}$-axis of $\left[\mathrm{Ni}(\mathrm{dddt})_{2}\right]^{-}$is approximately on or perpendicular to the $\left[\mathrm{NiS}_{4}\right]^{-}$plane while the $\mathrm{g}^{-}$ axis of $\left[\mathrm{Ni}(\mathrm{dmit})_{2}\right]^{-}$is on the plane, though DFT study of the complexes of this study and previously reported $\left[\mathrm{NiS}_{4}\right]^{-}$complexes indicate that the $\mathrm{g}_{\mathrm{y}}$-axis is on the $\left[\mathrm{NiS}_{4}\right]^{-}$ plane.
\end{abstract}

Keywords : Electron paramagnetic resonance, Single crystal EPR, Ni(III) complexes, $\left[\mathrm{NiS}_{4}\right]^{-}$, DFT

\section{INTRODUCTION}

$\mathrm{Ni}$ is of interest for its biological roles in many Ni-containing enzymes such as Urease, Methyl coenzyme $\mathrm{M}$ reductase, $\mathrm{CO}$ dehydrogenase, and Ni-containing superoxide dismutase $\mathrm{e}^{1-3}$ as well as for

Department of Chemistry, Kyungpook National University, Daegu 702-701, Republic of Korea

Tel: +82.53.950.5904 Fax:+82.53.950.6331 e-mail: leehi@knu.ac.kr

Journal of the Korean Magnetic Resonance Society 2012 June; 16(1): 78-90

http://dx.doi.org/10.6564/JKMRS.2012.16.1.078 
its usage in developing magnetic and conducting materials. ${ }^{4-9}$ To understand the roles of the Ni ions in the enzymes and the materials, many Ni model complexes have been invented and investigated. Among those, square planar Ni-bis(thiolene) complexes have been found to be able to catalyze redox reactions and to have delocalized molecular orbitals in the complex plane. ${ }^{10}$ These complexes tend to form linear-chain structure in their solid state to be the excellent precursor of conducting molecular solid. ${ }^{11-14}$ Interestingly, the Ni thiolate complexes can have several oxidation states without changing their coordination spheres. However, the redox active site, Ni or S, was not clearly identified. ENDOR (electron nuclear double resonance) and ESEEM (electron spin echo envelope modulation) have been employed to search the redox active portions of bis(maleonitriledithiolato)nickelate(III) $\left(\left[\mathrm{Ni}(\mathrm{mnt})_{2}\right]^{-}\right)$and bis((trifluoromethyl)ethylenedithiolato) nickelate(III) ([Ni(tfd $\left.\left.)_{2}\right]^{-}\right)$which are effective acceptor molecules for forming magnetic or conducting materials. ${ }^{13}$ In the present study, we carried out powder and single-crystal EPR (electron paramagnetic resonance) studies and DFT (density functional theory) calculations of two complexes, $\mathrm{FcCH}=\mathrm{CHPymCH}_{3}\left[\mathrm{Ni}(\mathrm{dmit})_{2}\right](\mathrm{Pym}=$ pyridinium, dmit ${ }^{2-}=2$-thioxo-1,3-dithiole-4,5-dithiolate) and $\mathrm{FcCH}=\mathrm{CHPymCH}_{3}\left[\mathrm{Ni}(\mathrm{dddt})_{2}\right] \cdot \frac{1}{2} \mathrm{H}_{2} \mathrm{O}$ $\left(\mathrm{dddt}^{2-}=5,6\right.$-dihydro-1,4-dithiin-2,3-dithiolato), to understand the details of the electronic structures of the square planar $\left[\mathrm{NiS}_{4}\right]^{\text {.complexes. }}$.

\section{EXPERIMENTAL}


$\mathrm{FcCH}=\mathrm{CHPymCH}_{3}\left[\mathrm{Ni}(\mathrm{dmit})_{2}\right](=$ trans-4-[2-(1-ferrocenyl)vinyl]-1-methyl pyridinium-bis(1,3dithiole-2-thione-4,5-dithiolato)nickelate(III)) was synthesized by following the previously published method. ${ }^{15} \quad \mathrm{FcCH}=\mathrm{CHPymCH}_{3}\left[\mathrm{Ni}(\mathrm{dddt})_{2}\right] \cdot \frac{1}{2} \mathrm{H}_{2} \mathrm{O} \quad$ (=trans-4-[2-(1-ferrocenyl)vinyl $]-1-$ methylpyridinium-bis(5,6-dihydro-1,4-dithiin-2,3-dithiolato)nickelate(III)) was prepared similarly to the synthetic method of $\mathrm{FcCH}=\mathrm{CHPymCH}_{3}\left[\mathrm{Ni}(\mathrm{dmit})_{2}\right]$ except for using $n-\mathrm{Bu}_{4} \mathrm{~N}\left[\mathrm{Ni}(\mathrm{dddt})_{2}\right]$ instead of $n$ - $\mathrm{Bu}_{4} \mathrm{~N}\left[\mathrm{Ni}(\mathrm{dmit})_{2}\right]$. Single crystals of the complex were grown by the electrochemical crystallization method under Ar atmosphere. ${ }^{15}$ X-ray diffraction data were collected on an EnrafNonius CAD-4 automatic diffractometer equipped with graphite-monochromated Mo-K $\alpha$ radiation $(\lambda=0.71073 \AA)$ at $293(2) \mathrm{K} .{ }^{15}$ The Structures were solved and refined using SHELXS-86 and SHELXS-93. Hydrogen atoms were theoretically added and included in the final refinement. X-band (9 GHz) EPR spectra were recorded on Jeol JES-TE300 ESR spectrometer using $100 \mathrm{kHz}$ field modulation. Single crystal EPR spectra were obtained using a home-made Goniometer. Experimental conditions are microwave (MW) frequency, $9.53-9.54 \mathrm{GHz}$, MW power, $20 \mathrm{~mW}$, time constant , $125 \mathrm{~ms}$ for powder samples and $64 \mathrm{~ms}$ for crystals, modulation amplitude, $0.05 \mathrm{G}$, and temperature, $25^{\circ} \mathrm{C}$. Hartree-Fock (HF) and density functional theory (DFT) with the B3LYP exchange-correlation functional theories were adapted to compute the geometries and the energies. ${ }^{18}$

\section{RESULTS AND DISCUSSION}

\section{Crystal Structures}


Crystallographic analyses of the complexes revealed that both the crystals of $\mathrm{FcCH}=\mathrm{CHPymCH}_{3}\left[\mathrm{Ni}(\mathrm{dddt})_{2}\right] \cdot 1 / 2 \mathrm{H}_{2} \mathrm{O}$ and $\mathrm{FcCH}=\mathrm{CHPymCH}_{3}\left[\mathrm{Ni}(\mathrm{dmit})_{2}\right]$ were formed in monoclinic crystal system. Figure 1 displays the crystal bases of the two complexes. Ni(III) ions are coordinated by four sulfur atoms to form square planar geometry with $D_{2 h}$ symmetry in both $\left[\mathrm{Ni}(\mathrm{dddt})_{2}\right]^{-}$and $\left[\mathrm{Ni}(\mathrm{dmit})_{2}\right]^{-}$. Two different orientations of $\left[\mathrm{Ni}(\mathrm{dddt})_{2}\right]^{-}$are found in the crystal of $\mathrm{FcCH}=\mathrm{CHPymCH}_{3}\left[\mathrm{Ni}(\mathrm{dddt})_{2}\right] \cdot 1 / 2 \mathrm{H}_{2} \mathrm{O}$ while only one orientation of $\left[\mathrm{Ni}(\mathrm{dmit})_{2}\right]^{-}$exists in $\mathrm{FcCH}=\mathrm{CHPymCH}_{3}\left[\mathrm{Ni}(\mathrm{dmit})_{2}\right] . \quad$ In $\quad \mathrm{FcCH}=\mathrm{CHPymCH}_{3}\left[\mathrm{Ni}(\mathrm{dddt})_{2}\right] \bullet 1 / 2 \mathrm{H}_{2} \mathrm{O}, \quad$ two independent $\left[\mathrm{Ni}(\mathrm{dddt})_{2}\right]^{-}$planes are near orthogonal. Ni-S bond lengths $(2.1375(13)-2.1463(11) \AA)$ of $\left[\mathrm{Ni}(\mathrm{dddt})_{2}\right]^{-}$are a little shorter than those $(2.162(3)-2.174(11) \AA)$ of $\left[\mathrm{Ni}(\mathrm{dmit})_{2}\right]^{-}$. These lengths are close to the general Ni-S bond length of $2.5 \AA$. And the average S-Ni-S bite angle of $\left[\mathrm{Ni}(\mathrm{dddt})_{2}\right]^{-}$is found to be $91.9^{\circ}$ which is smaller than $93.0^{\circ}$ of $\left[\mathrm{Ni}(\mathrm{dmit})_{2}\right]^{-15}$

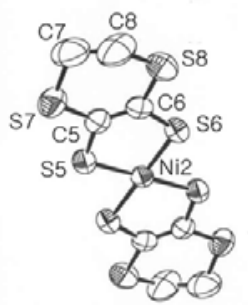

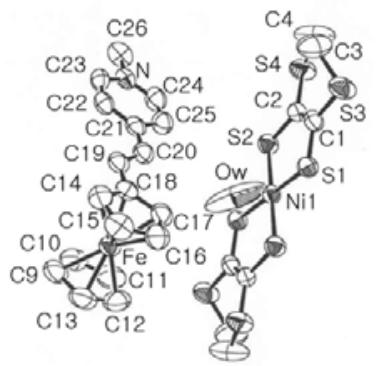

(a)

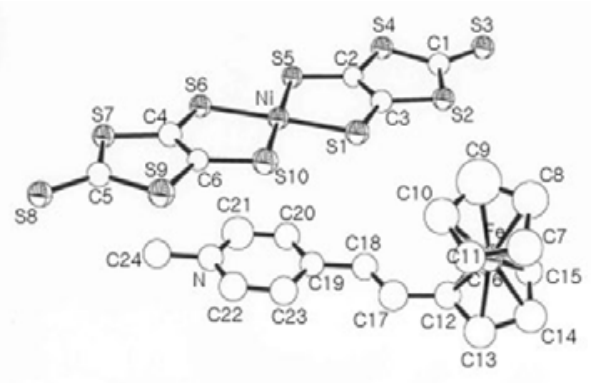

(b)

Figure 1. Crystal bases of (a) $\mathrm{FcCH}=\mathrm{CHPymCH}_{3}\left[\mathrm{Ni}(\mathrm{dddt})_{2}\right] \cdot 1 / 2 \mathrm{H}_{2} \mathrm{O}$ and (b) $\mathrm{FcCH}=\mathrm{CHPymCH}_{3}\left[\mathrm{Ni}(\mathrm{dmit})_{2}\right]$ 
Figure 2(a) is the unit cell view of $\mathrm{FcCH}=\mathrm{CHPymCH}_{3}\left[\mathrm{Ni}(\mathrm{dddt})_{2}\right]^{1 / 1} / 2 \mathrm{H}_{2} \mathrm{O}$ crystal along the crystal $b$ axis. In the unit cell, four $\mathrm{FcCH}=\mathrm{CHPymCH}_{3}{ }^{+}$units, four $\left[\mathrm{Ni}(\mathrm{dddt})_{2}\right]^{-}$, and two water molecules are found. There are two orientations of $\left[\mathrm{Ni}(\mathrm{dddt})_{2}\right]$. One of them is normal to the $b$ axis and the other is normal to the $c$ axis. Figure 2(b) is the unit cell view of $\mathrm{FcCH}=\mathrm{CHPymCH}_{3}\left[\mathrm{Ni}(\mathrm{dmit})_{2}\right]$ crystal along the crystal $b$ axis. There are two $\mathrm{FcCH}=\mathrm{CHPymCH}_{3}{ }^{+}$ units and two $\left[\mathrm{Ni}(\mathrm{dmit})_{2}\right]^{-}$units in the unit cell. The $\left[\mathrm{Ni}(\mathrm{dmit})_{2}\right]^{-}$planes are normal to the $b$ axis.

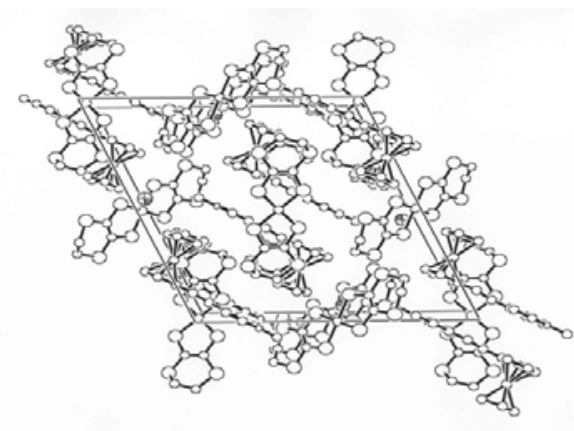

(a)

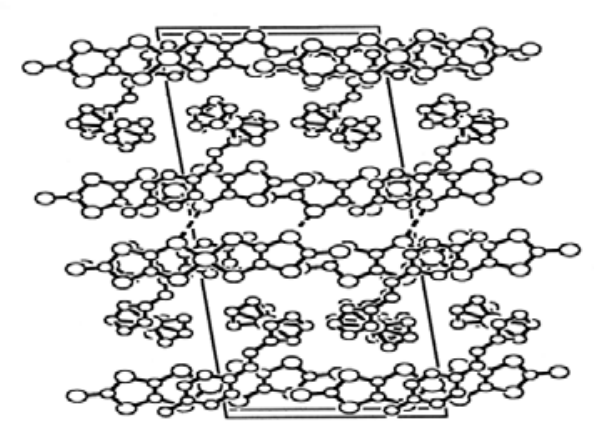

(b)

Figure 2. Unit cell views of (a) $\mathrm{FcCH}=\mathrm{CHPymCH}_{3}\left[\mathrm{Ni}(\mathrm{dddt})_{2}\right]^{1 / 1} / 2 \mathrm{H}_{2} \mathrm{O}$ and (b) $\mathrm{FcCH}=\mathrm{CHPymCH}_{3}\left[\mathrm{Ni}(\mathrm{dmit})_{2}\right]$ along the crystal $b$ axes.

\section{Electron Paramagnetic Resonance}

Figure 3 shows the paramagnetic centers and room temperature power EPR spectra of

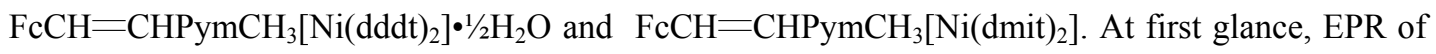
$\mathrm{FcCH}=\mathrm{CHPymCH}_{3}\left[\mathrm{Ni}(\mathrm{dddt})_{2}\right]^{1 / 1} / 2 \mathrm{H}_{2} \mathrm{O}$ (Figure $3(\mathrm{a})$ ) seems to be axially symmetric. However, 
detailed EPR study with the single-crystal sample of the complex revealed that the complex had a rhombic EPR feature with $g_{x}=2.063, g_{y}=2.055$, and $g_{z}=2.039$. This EPR signal arises from the $\left[\mathrm{NiS}_{4}\right]^{-}$core, $\left[\mathrm{Ni}(\mathrm{III})(\mathrm{dddt})_{2}\right]^{-}$. The rhombicity depends on the delocalization of the unpaired delectron spin. EPR of $\mathrm{FcCH}=\mathrm{CHPymCH}_{3}\left[\mathrm{Ni}(\mathrm{dmit})_{2}\right]$ also arises from the $\left[\mathrm{NiS}_{4}\right]^{-}$core, $\left[\mathrm{Ni}(\mathrm{III})(\mathrm{dmit})_{2}\right]^{-}$. (figure 3(b)) The observed rhombicity, $\mathrm{g}_{\mathrm{x}}=2.10, \mathrm{~g}_{\mathrm{y}}=2.06$, and $\mathrm{g}_{\mathrm{z}}=2.00$, of $\left[\mathrm{Ni}(\mathrm{dmit})_{2}\right]^{-}$is bigger than that of $\left[\mathrm{Ni}(\mathrm{dddt})_{2}\right]^{-}$.

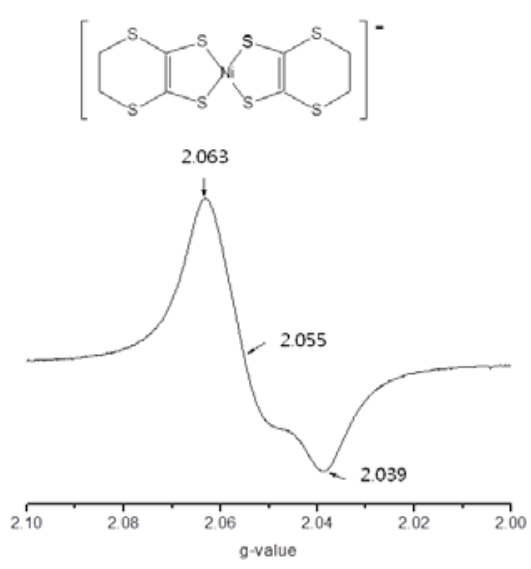

(a)

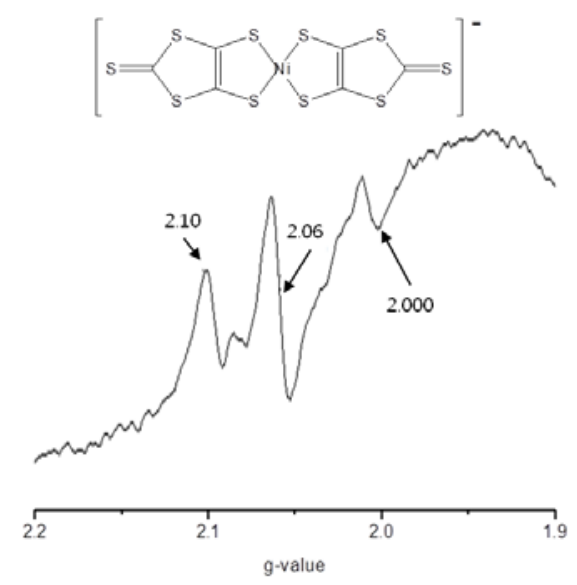

(b)

Figure 3. Paramagnetic centers and room temperature powder EPR spectra of (a)

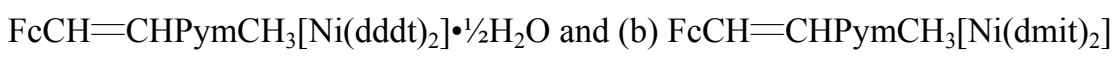

Single crystal EPR spectra of the complexes are obtained for understanding the differences of the rhombicities and electronic structures of the two complexes. Figure 4 depicts such spectra obtained by rotating the crystals about the $b$ axis of each crystal. Here, the $b$ axis was placed to be 
normal to the external magnetic field direction. When we define the direction of the external magnetic field, $\mathbf{B}_{\mathbf{0}}$, with the angles $\Theta$ and $\Phi$ relative to the $\mathbf{g}$ axes as in figure 5, the observed $g$ values ( $\left.g_{\mathrm{obs}}\right)$ can be calculated by $\mathrm{g}_{\mathrm{obs}}=\left(\mathrm{g}_{\mathrm{x}}{ }^{2} \sin ^{2} \Theta \cos ^{2} \Phi+\mathrm{g}_{\mathrm{y}}{ }^{2} \sin ^{2} \Theta \sin ^{2} \Phi+\mathrm{g}_{\mathrm{z}}{ }^{2} \cos ^{2} \Theta\right)^{1 / 2} \cdot{ }^{16}$

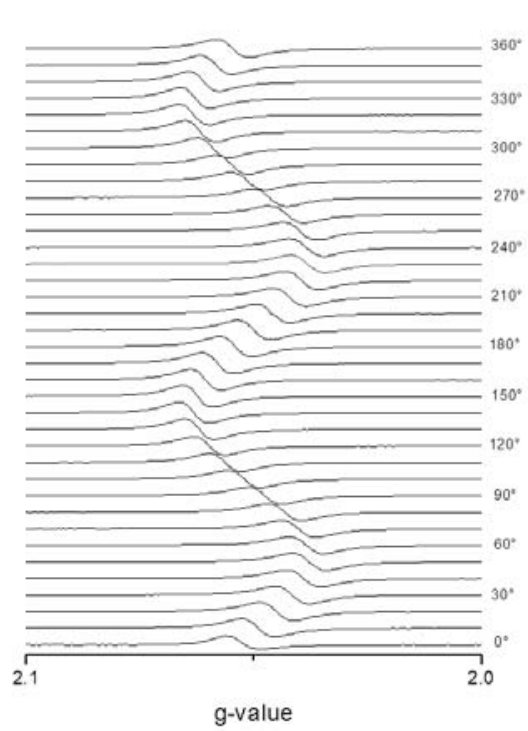

(a)

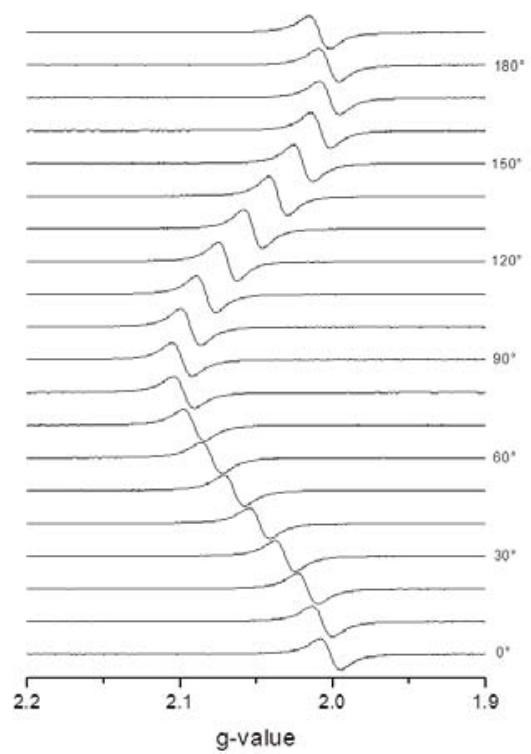

(b)

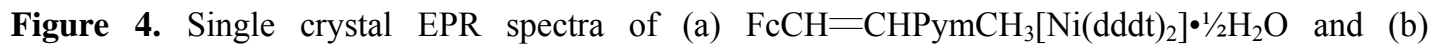
$\mathrm{FcCH}=\mathrm{CHPymCH}_{3}\left[\mathrm{Ni}(\mathrm{dmit})_{2}\right]$. The crystals were rotated about the $b$ axis of each crystal. The $b$ axis was placed normal to the external magnetic field. 


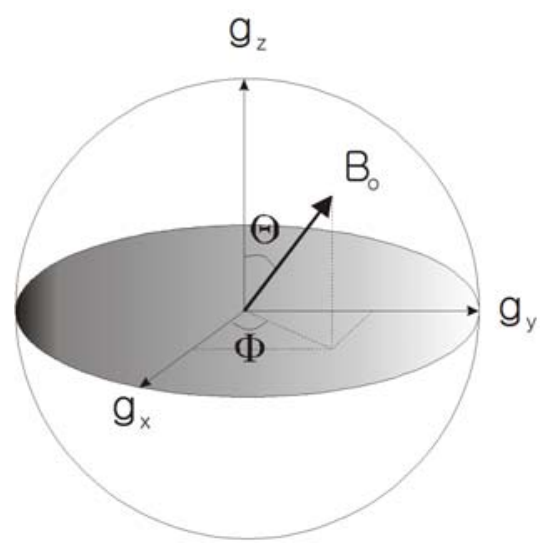

Figure 5. Definition of the external magnetic field, $\mathbf{B}_{\mathbf{0}}$, with respect to the $\mathbf{g}$ axes

The observed $g$ values of $\mathrm{FcCH}=\mathrm{CHPymCH}_{3}\left[\mathrm{Ni}(\mathrm{dddt})_{2}\right]^{\bullet} 1 / 2 \mathrm{H}_{2} \mathrm{O}$ could be well calculated with $\Phi=0^{\circ}, g_{x}=2.0635, g_{z}=2.0395$ and an arbitrary phase change of $\eta \cdot\left(g_{o b s}=\left(g_{x}{ }^{2} \sin ^{2}(\Theta-\eta)+g_{x}{ }^{2} \cos ^{2}(\Theta-\right.\right.$ $\eta))^{1 / 2}$. (Figure 6(a)) This indicates that the crystal was rotated about $g_{y}$ axis. Since the EPR data were obtained by rotating the crystal about the crystal $b$ axis, $\mathrm{g}_{\mathrm{y}}$ axis is coincident with the $b$ axis. Because one of the $\left[\mathrm{Ni}(\mathrm{dddt})_{2}\right]^{-}$planes is along the $b$ axis and the other is normal to the $b$ axis, the $\mathrm{g}_{\mathrm{y}}$ axis of $\left[\mathrm{Ni}(\mathrm{dddt})_{2}\right]^{-}$is on the plane or normal to the plane. The observed $\mathrm{g}$ values of $\mathrm{FcCH}=\mathrm{CHPymCH}_{3}\left[\mathrm{Ni}(\mathrm{dmit})_{2}\right]$ could also be well calculated with $\Phi=0^{\circ}, \mathrm{g}_{\mathrm{x}}=2.099, \mathrm{~g}_{\mathrm{z}}=2.002$ and an arbitrary phase change of $\eta$. (Figure $6(\mathrm{~b}))$ Therefore, analogously to $\left[\mathrm{Ni}(\mathrm{dddt})_{2}\right]^{-}$, the $\mathrm{g}_{\mathrm{y}}$ axis of $\left[\mathrm{Ni}(\mathrm{dmit})_{2}\right]^{-}$is normal to the $\left[\mathrm{NiS}_{4}\right]^{-}$plane. 


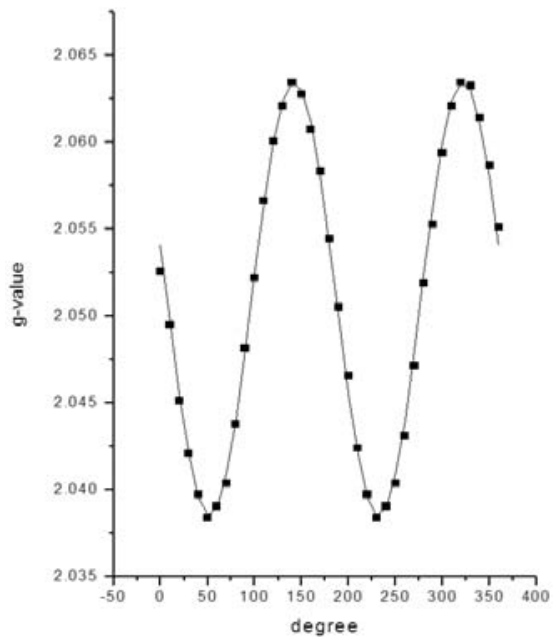

(a)

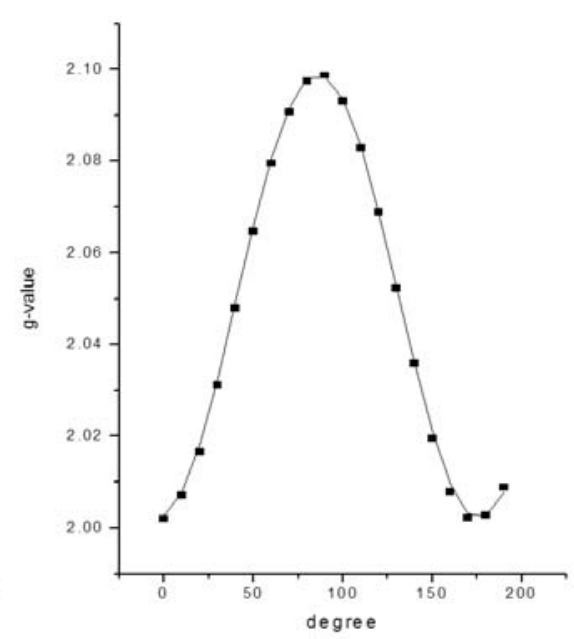

(b)

Figure 6. Observed $g$ vales (dark square) and calculated $g$ values (solid line) of (a) $\mathrm{FcCH}=\mathrm{CHPymCH}_{3}\left[\mathrm{Ni}(\mathrm{dddt})_{2}\right] \bullet \stackrel{1}{2} \mathrm{H}_{2} \mathrm{O}$ and (b) $\mathrm{FcCH}=\mathrm{CHPymCH}_{3}\left[\mathrm{Ni}(\mathrm{dmit})_{2}\right]$ (see text)

Though the core structures are similar, the rhombicity of $\left[\mathrm{Ni}(\mathrm{dddt})_{2}\right]^{-}, \Delta \mathrm{g}=\mathrm{g}_{\mathrm{x}}-\mathrm{g}_{\mathrm{z}}=0.024$, is smaller than that of $\left[\mathrm{Ni}(\mathrm{dmit})_{2}\right]^{-}, \Delta \mathrm{g}=\mathrm{g}_{\mathrm{x}}-\mathrm{g}_{\mathrm{z}}=0.097$. These are still smaller than the reported values of $\left[\mathrm{Ni}(\mathrm{mnt})_{2}\right]^{-}$and $\left[\mathrm{Ni}(\mathrm{tfd})_{2}\right]^{-}$which have the same $\left[\mathrm{NiS}_{4}\right]^{-}$core structures. ${ }^{17}$ The EPR signals of $\left[\mathrm{NiS}_{4}\right]^{-}$are arising from $\mathrm{d}^{7}$ configuration in which the unpaired electron spin is delocalized in the $\left[\mathrm{NiS}_{4}\right]^{-}$plane. EPR/ENDOR/ESEEM investigations of $\left[\mathrm{Ni}(\mathrm{mnt})_{2}\right]^{-}$found that the unpaired electron spin density is $\rho(\mathrm{Ni})=0.25, \rho(\mathrm{S})=0.20$, and $\rho\left(\left[\mathrm{NiS}_{4}\right]^{-}\right)=0.85 .^{17}$

\section{DFT calculation}


To understand the small rhombicity in $\left[\mathrm{Ni}(\mathrm{dddt})_{2}\right]^{-}$and $\left[\mathrm{Ni}(\mathrm{dmit})_{2}\right]^{-}$, density functional calculation is performed based on the crystal structures. ${ }^{18}$ Figure 7 shows the shapes of SOMO (singly occupied molecular orbital) calculated from DFT calculations and atomic numbering schemes. As in the figure, the unpaired electron spin is mostly delocalized on $\left[\mathrm{NiS}_{4}\right]^{-}$planes. Table 1 lists the spin density distributions in $\left[\mathrm{Ni}(\mathrm{dddt})_{2}\right]^{-}$and $\left[\mathrm{Ni}(\mathrm{dmit})_{2}\right]^{-}$.

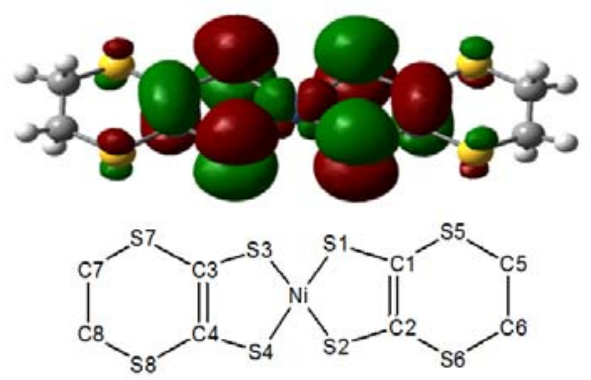

(a)

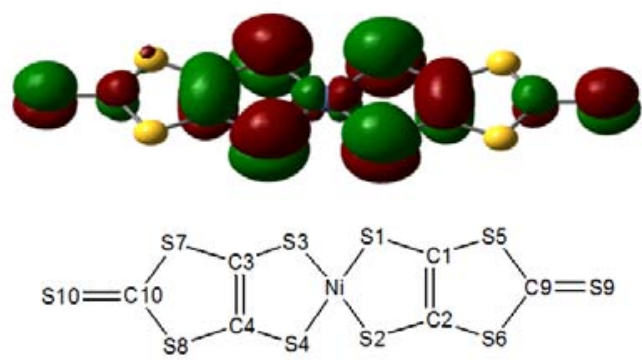

(b)

Figure 7. The shapes of SOMOs and atomic numbering schemes of (a) $\left[\mathrm{Ni}(\mathrm{dddt})_{2}\right]^{-}$and (b) $\left[\mathrm{Ni}(\mathrm{dmit})_{2}\right]^{-}$

Table 1. Spin density distributions of $\left[\mathrm{Ni}(\mathrm{dddt})_{2}\right]^{-}$and $\left[\mathrm{Ni}(\mathrm{dmit})_{2}\right]^{-}$obtained by DFT calculations

\begin{tabular}{c|c|c}
\hline \multirow{2}{*}{ Atom } & \multicolumn{2}{|c}{ Spin density } \\
\cline { 2 - 3 } & {$\left[\mathrm{Ni}(\mathrm{dddt})_{2}\right]^{-}$} & {$\left[\mathrm{Ni}(\mathrm{dmit})_{2}\right]^{-}$} \\
\hline $\mathrm{Ni}$ & 0.06 & 0.17 \\
\hline$[\mathrm{S} 1, \mathrm{~S} 2, \mathrm{~S} 3, \mathrm{~S} 4]$ & 0.36 & 0.60 \\
\hline$[\mathrm{C} 1, \mathrm{C} 2, \mathrm{C} 3, \mathrm{C} 4]$ & 0.36 & 0.12 \\
\hline$[\mathrm{S} 5, \mathrm{~S} 6, \mathrm{~S} 7, \mathrm{~S} 8]$ & 0.22 & 0.04 \\
\hline
\end{tabular}


The calculated spin densities of $\left[\mathrm{Ni}(\mathrm{dmit})_{2}\right]^{-}$are similar to the reported values of $\left[\mathrm{Ni}(\mathrm{mnt})_{2}\right]^{-17}$ This explains the similarity of EPR features of $\left[\mathrm{Ni}(\mathrm{dmit})_{2}\right]^{-}$and $\left[\mathrm{Ni}(\mathrm{mnt})_{2}\right]^{-} \cdot \rho(\mathrm{Ni})=0.06$ of $\left[\mathrm{Ni}(\mathrm{dddt})_{2}\right]^{-}$is much smaller than those of other $\left[\mathrm{NiS}_{4}\right]^{-}$complex ions. The spin density on $\left[\mathrm{NiS}_{4}\right]^{-}$ core of $\left[\mathrm{Ni}(\mathrm{dddt})_{2}\right]^{-}$is about the half of other $\left[\mathrm{NiS}_{4}\right]^{-}$complexes. This agrees with the spin density of 0.32 in $\mathrm{C}=\mathrm{C}$. In $\left[\mathrm{Ni}(\mathrm{dddt})_{2}\right]^{-}$, the $\pi$-orbitals of $[\mathrm{S} 5, \mathrm{~S} 6, \mathrm{~S} 7, \mathrm{~S} 8]$ have some spin density while those of $\left[\mathrm{Ni}(\mathrm{dmit})_{2}\right]^{-}$does not. This suggests that the ligand of $\left[\mathrm{Ni}(\mathrm{dddt})_{2}\right]^{-}$has $\pi$-conjugation as in figure 8 and SOMO has anti-bonding characters so that the spin distributes more widely. But this kind of $\pi$ conjugation is not expected in $\left[\mathrm{Ni}(\mathrm{dmit})_{2}\right]^{-}$. Overall, low spin density in d-orbitals of $\left[\mathrm{Ni}(\mathrm{dddt})_{2}\right]^{-}$and high spin density in the $\pi$-system of the ligand attribute the small rhombicity of EPR.

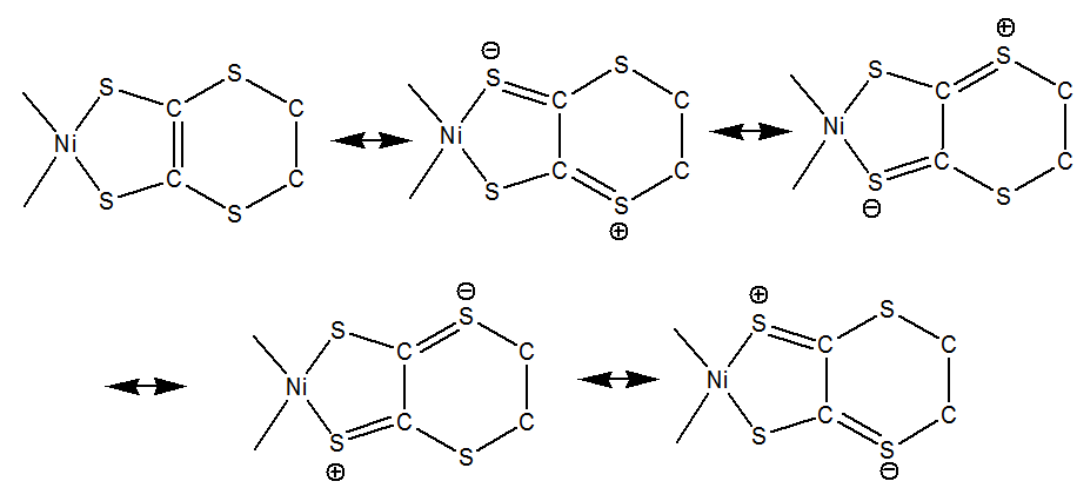

Figure 8. A suggested -conjugation system present in $\left[\mathrm{Ni}(\mathrm{dddt})_{2}\right]^{-}$

\section{Summary}


Single crystal EPR studies of $\mathrm{FcCH}=\mathrm{CHPymCH}_{3}\left[\mathrm{Ni}(\text { dddt })_{2}\right]^{1 / 1} / 2 \mathrm{H}_{2} \mathrm{O}$ and $\mathrm{FcCH}=\mathrm{CHPymCH}_{3}\left[\mathrm{Ni}(\mathrm{dmit})_{2}\right]$ found that the $\mathrm{g}_{\mathrm{y}}$ axis of $\left[\mathrm{Ni}(\mathrm{dddt})_{2}\right]^{-}$is normal to or on the $\left[\mathrm{NiS}_{4}\right]^{-}$ plane and that of $\left[\mathrm{Ni}(\mathrm{dmit})_{2}\right]^{-}$is normal to the $\left[\mathrm{NiS}_{4}\right]^{-}$plane. Even though the rhombicity of EPR could be explained by DFT calculations, the directions of g-axes predicted by EPR are contradict to the results of DFT calculations where the $\mathrm{g}_{\mathrm{y}}$ axes of the complexes are on the $\left[\mathrm{NiS}_{4}\right]^{-}$planes and the $\mathrm{g}_{\mathrm{z}}$ axes are normal to the planes. Current EPR study also contradicts the previous study of $\left[\mathrm{Ni}(\mathrm{mnt})_{2}\right]^{\top}$ where the $g_{y}$ axis lies on the $\left[\mathrm{NiS}_{4}\right]^{-}$planes and the $\mathrm{g}_{\mathrm{z}}$ axis is normal to the plane. In this study, the rotation of the crystals was performed only one axis. Further experiments including full rotation of the crystals about other axes will give insights into the detailed electronic structures of $\left[\mathrm{NiS}_{4}\right]^{-}$.

\section{Acknowledgment}

This research was supported by Basic Science Research Program through the National Research Foundation of Korea (NRF) funded by the Ministry of Education, Science and Technology (20100024929)

\section{REFERENCES}

1. (a) B. Jaun, Chimia 48, 50, (1994). (b) J. G. Ferry, Annu. Rev. Microbiol. 49, 305 (1995).

2. S. B. Mulrooney, R. P. Hausinger, FEMS Microbiol. Rev. 27, 239 (2003).

3. S. Ciurli, S. Mangan, in "Handbook on metalloproteins" (I. Bertini, A. Sigel, H. Sigel, Eds.), pp. 669-708, Marcel Dekker, New York, 2001. 
4. P. Day, M. Kurmoo, T. Mallah, I. R. Marsden, R. H. Friend, F. L. Pratt, W. Hayes, D. Chasseau, J. Gaultier, G. Bravic, L. Ducasse, J. Am. Chem. Soc. 114, 10722 (1992).

5. M. Kurmoo, A. W. Graham, P. Day, S. J. Coles, M. B. Hurstouse, J. L. Caulfield, J. Singleton, F. L. Pratt, W. Hayes, L. Ducasse and P. Guionneau, J. Am. Chem. Soc. 117, 12209 (1995).

6. T. Enoki, J. Yamaura, A. Miyazaki, Bull. Chem. Soc. Jpn 70, 2005 (1997).

7. E. Coronado, J. R. Galan-Mascaros, C. J. Gomez-Garcia, V. Laukhin, Nature 408, 447 (2000).

8. S. Uji, H. Shinagawa, T. Yakabe, Y. Terai, M. Tokumoto, A. Kobayashi, H. Tanaka, H. Kobayashi, Nature 410, 908 (2000).

9. H. Fujiwara, E. Fujiwara, Y. Nakazawa, B. Z. Narymbetov, K. Kato, H. Kobayashi, A. Kobayashi, M. Tokumoto, P. Cassoux, J. Am. Chem. Soc. 123, 306 (2001).

10. A. Volbeda, E. Garcin, C. Piras, A. L. de Lacey, V. M. Fernandez, E. C. M. Frey, J. C. Fontecilla-Camps, J. Am. Chem. Soc. 118, 12989 (1996).

11. (a) A. H. Maki, N. Edelstein, A. Davison, R. H. Holm, J. Am. Chem. Soc. 86, 4580 (1964). (b) M. Sano, H. Adachi, H. Yamatera, Bull. Chem. Soc. Jpn 54, 2636 (1981). (c) G. N. Schrauzer, V. P. Mayweg, J. Am. Chem. Soc. 87, 3586 (1965).

12. W. E. Hatfield, in "Molecular Metal" (W. E. Hatfield, Ed.), Plenum, New York, 1979.

13. J. T. Devreese, R. P. Evrard, V. E. Van Doren, in "Highly Conducting One-Dimensional Solids" (J. T. Devreese, R. P. Evrard, V. E. Van Doren, Eds.), Plenum, New York, 1979.

14. J. S. Miller, in "Extended Linear Chain Compounds" (J. S. Miller, Ed.), Plenum, New York, 1982 (Vol. 1 and 2), 1983 (Vol.3).

15. Y. -K. Han, D. -K. Seo, H. Kang, W. Kang, D. -Y. Noh, Inorg. Chem. 43, 7294 (2004).

16. A. Abragam, B. Bleaney, in "Electron Paramagnetic Resonance of Transition Metal Ions" (A. Abragam, B. Bleaney, 2nd eds.), Clarendon Press, Oxford, 1970.

17. J. E. Huyett, S. B. Choudhury, D. M. Eichhorn, P. A. Bryngelson, M. J. Maroney, B. M. Hoffman, Inorg. Chem. 37, 1361 (1998).

18. M. J. Frisch, G. W. Truck, H. B. Schlegel, P. M. W. Gill, B. G. Johnson, M. A. Robb, J. R. Cheeseman, T. Keith, G. A. Peterson, J. A. Montgomery, K. Raghavachari, M. A. Al-Laham, V. G. Zakrzewski, J. V. Ortiz, J. B. Foreman, J. Cioslowski, B. B. Stefanov, A. Nanayakara, M. Challacombe, C. Y. Peng, P. Y. Ayala, W. Chen, M. W. Wong, J. L. Andres, E. S. Replogle, R. Gomperts, R. L. Martin, D. J. Fox, J. S. Binkley, D. J. Defrees, J. Baker, J. P. Stewart, M. HeadGordon, C. Gonzalez, J. A. Pople, Gaussian 94, Gaussian, Inc. Pittsburgh, PA (1995). 